\title{
Theorems in Quran about the Creation of Insects and Its Diversity in Undaan Park Surabaya
}

\author{
$\mathrm{N}$ 'Aini ${ }^{1}$, I A Wira ${ }^{2}$, V Y Pratami ${ }^{3}$ \\ ${ }^{1}$ Islamic Building School of Jagad Alimussirry Surabaya, Indonesia \\ ${ }^{2}$ Biology Postgraduate Program, Universitas Airlangga, Indonesia \\ ${ }^{3}$ Biology Postgraduate Program, Universitas Sebelas Maret, Indonesia \\ Email: ainibiologi@gmail.com
}

\begin{abstract}
In the Al-quran there are many verses that explain the animals that exist in this universe, one of which is about Insect. The research on Insect diversity around the Surabaya Undaan Park aims to describe the diversity of Insects and compare the number of members of each order in the Insect class around the Surabaya Undaan Park and look for their relevance to the Qur'anic proposition about the creation of Insects. The method used in this research assignment was observation, which was to go directly to the field to catch Insects in 5 plots in the vicinity of Surabaya Undakan Park with 4 repetitions in each plot, then collect data to be identified. Based on the results of observations, collection and identification, it can be found that there are various Insects in the area. This was evidenced by the discovery of various orders from Insectas, among others: Order Lepidoptera, Order Odonata, Order Hymenoptera, Order Diptera, and Order Orthoptera. Comparison of the number of species from each order is different. The most dominant number of species is in the order of Lepidoptera which was then followed by the order Hymenoptera.
\end{abstract}

Keywords: Spiritual Value, Biology, Plant Growth and Development, Seed Germination, Fruit Maturation

\section{INTRODUCTION}

The Qur'an is the greatest miracle of all time given to the Prophet Muhammad. In the Qur'an there are various kinds of sources of knowledge. Until now, scientists are still exploring and developing the knowledge contained in the Qur'an. One feature of the Qur'an is that it allows its interpretation to continue to develop, for example, which is contained in the letter Al Hajj (22) verse 73 which in the letter Allah explains about the creation of an animal / insect which when united humans cannot create it even though a fly.

Insects are a type of invertebrate with a very large number and types. Insects or better known as insects are animals with segmented legs that are often found in many places with diverse types. This is because the Insect class has a very high level of adaptation. Insect size is relatively small and is the first time successfully colonizing the earth because of its high adaptability to its habitat (Akhmad, 2002). There are two roles of insects in everyday life, which are harmful and beneficial. One of the roles that benefits insects for humans and plants is as pollinating animals which naturally help the survival of growing plants. The role of insects is substantial needed by regions with a large number of urban parks, for example the city of Surabaya. 
Undaan Park is one of the many parks scattered in the city of Surabaya which is empowered by the City Government. The park, which was inaugurated in 2009, is a manifestation of social and environmental responsibility that functions as an absorbent agent of pollution and to beautify the city order. Behind the function of the Undaan park as mentioned above, without realizing it turns out that in the Undaan Park itself saves a lot of animals that biologically help the survival of various kinds of plants that grow in it.

The formulation of the problem of this research is how Insect diversity in the Taman Undaan area and how the comparison of the number of members of each order in the Insecta class in the Taman Undaan area. The purpose of this research assignment was to describe the diversity of Insects in the Undaan Park area and to compare the number of members of each order in the Insecta class located in the Undaan Park area. In addition, in this study we will also look for the relationship between the diversity of insects found in the Surabaya Undaan Park area and the Qur'anic proposition which is the basis for creating insects on this earth.

\section{METHOD}

This type of research on Insect diversity in the Taman Undaan area is observation. This is because researchers do not just observe the diversity of Insects in the Taman Undaan area, but do research directly, the results of which are collected in the form of Insectarium. The place for research on Insect diversity was carried out in the Surabaya Undaan Park area located on Jalan Undaan Kulon Surabaya. The study was conducted for 3 months. The research and data collection was first conducted on September 2018 and ended on Friday, November 29, 2018. Research and data collection were carried out in the morning and evening, each with 4 repetitions.

The equipment needed in the research and data collection of Insect in the Undaan Park area are 3 nets to catch Insecta, a box of insects made of cardboard, 2 plastic jars to anesthetize Insects, a $1 \mathrm{ml}$ syringe to inject formalin solution into the Insect's body and camera which is used to document Insects. While the material needed is styrofoam to fix Insect catches, chloroform solution, 4\% formalin solution for the process of preservation, cotton, pin, and camphor for preservation. The expected target in this study is the Insectarium as an indicator of the diversity of Insects in the Surabaya Undaan Park area. The research was conducted by capturing and taking objects in the form of various types of Insects in the Surabaya Undaan Park area and then preserving them so that Insectariums as mentioned above can be made.

This research is conducted by first preparing the tools and materials to be used. Before the insect is captured using a net, the insect is first taken to be documented. After taking pictures, the insects are carefully captured so that no part of the insect is damaged during the capture procession. Then the insects are inserted into plastic jars that have been previously filled with cotton which has been moistened with chloroform to anesthetize the captured insects to death. Dead insects are then carefully moved over styrofoam to be fixed. This fixation is done using a pin. The pin needle is installed to form a sharp angle to the body part of the insect (not inserted), so that it can minimize damage to the insect's body parts which will be preserved. Insects are positioned in such a way so that all the body parts of the insect are visible. Both insect wings are stretched and it is recommended that one type of insect be fascinated with a different position, so that the dorsal and ventral positions will appear. This is so that insects are more easily observed and identified. Insects that have been fixed, then smeared with $4 \%$ formalin using a brush to be preserved. For insects with a large enough size, formalin injections need to be done using a spuid so that the insects don't rot. After that, identification of insects was carried out using 
the Insect book Halimun Mountain Park in West Java.

\section{RESULT AND DISCUSSION}

Table. I Types of insects in the Undaan Park area

\begin{tabular}{|c|c|c|c|c|c|}
\hline No & Ordo & Family & Genus & Spesies & Number \\
\hline \multirow{9}{*}{1.} & \multirow{9}{*}{ Lepidoptera } & Hesperideae & Calforis & C. bromus & 3 \\
\hline & & \multirow{5}{*}{ Pieridae } & Delias & D. periboea & 7 \\
\hline & & & Leptosia & L.nina & 7 \\
\hline & & & \multirow{2}{*}{ Eurema } & E.hecabe & 9 \\
\hline & & & & E. alitha & 7 \\
\hline & & & Appias & A. libythea olferna & 6 \\
\hline & & \multirow{3}{*}{ Nymphalidae } & Elymnias & E. hypermnesta & 7 \\
\hline & & & Junonia & J. atlites & 6 \\
\hline & & & Euploea & E.gamelia & 6 \\
\hline \multirow{2}{*}{2.} & \multirow{2}{*}{ Odonata } & \multirow{2}{*}{ Libellulidae } & Orthetrum & O. sabina & 2 \\
\hline & & & Brachythemis & B. contaminate & 7 \\
\hline \multirow{4}{*}{3.} & \multirow{4}{*}{ Hymenoptera } & \multirow{2}{*}{ Vespidae } & Rhyncium & R. haemorrhaidale & 7 \\
\hline & & & Ropalidia & R. fasciat ${ }^{*}$ & 6 \\
\hline & & \multirow{2}{*}{ Apidae } & Apis & A. cerana & 5 \\
\hline & & & Xylocopa & X. confuse & 4 \\
\hline \multirow{2}{*}{4.} & \multirow{2}{*}{ Diptera } & Muscidae & Musca & M. domestica & 1 \\
\hline & & Sarchopagidae & Sarchopaga & S. carnaria & 1 \\
\hline 5. & Orthoptera & Acrididae & Phlaeoba & P. fomusa & 4 \\
\hline
\end{tabular}

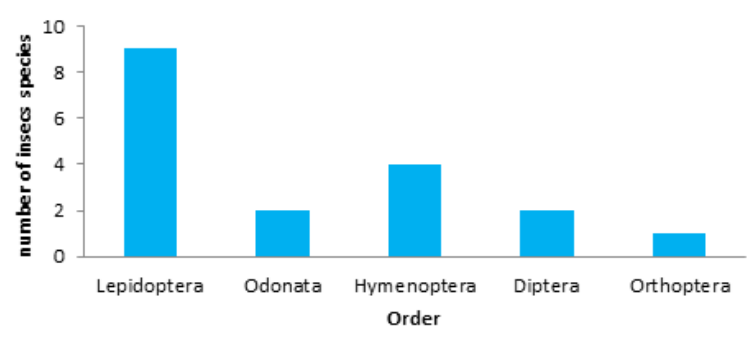

Figure 1. Comparison of the number of insect species in each ordo

\section{CONCLUSION}

In the Qur'an there are letters that are specifically told about insects, namely Surat An Naml (ant), Surat An Nahl (bee), Surat Al Ankabut (spider). The existence of letters in the Koran is an important spotlight to be studied more deeply why Allah chose insect names as letters in the Qur'an. Here is one of the verses related to insects in the Qur'an:

\section{QS An Nahl 78}

"And your Lord reveals to bees make nests in the hills, in wood trees, and in places that make people", which mean keil animals in the form of insects
The results showed that in the area of Taman Undaan there were 5 types of insects (Table I)
Based on this paragraph, it can be seen that in general insect habitats are in the mountains, trees and places provided by humans in the form of cultivation, especially insects and bee groups. In this study, the highest diversity of insects was found in areas with the highest number of plants.

2. QS An-naml: 18

"Until when they come to the valley of the ants, an ant says: Ants, enter into your nests, that you may not be trampled by Solomon and his army, while they are not aware".

\section{QS Al-baqoroh: 26}

"Indeed, Allah is not reluctant to make a parable in the form of a mosquito or lower than that. As for those who believe, they are convinced that the parable is true of their god, but those who disbelieve say: does God mean this to be a parable? With this parable, many were led astray by God, and with that parable (also) many were given instructions. And nothing is misled by God except those who are wicked". 


\section{QS Muhammad: 15}

"(What is) the parable (inhabitant) of heaven promised to those who are devoted in which there are rivers of water that do not change their taste and smell, the rivers of milk that do not change taste, the rivers of the khamar (arak) which tastes great for drinkers and rivers of honey filtered, and they get in it all kinds of fruits and forgiveness from their god, same as those who are eternal in hell and given minuan with boiling water that cuts cut the intestines"

\section{QS Al-Hajj: 73}

"O mankind, a parable has been made, so listen to you the parable. Surely everything you excite besides Allah cannot create a fly, even though they unite to create it. And if the fly takes something from them, they can't take it back from the fly. Very weak worshiping and very weak worshiped".

In general, based on the results of research conducted, it can be seen that all species collected are kingdom Animalia, Arthropod phylum, and Insect class. From the observations for 3 months with $4 \mathrm{x}$ observations namely morning and evening, the species obtained can be grouped according to the order which is divided into 5 orders, namely order Lepidoptera, order Odonata, order Hymenoptera, order Diptera, and order Orthoptera. Each order has its own characteristics that can distinguish from others so that it can be used for identification keys.

The Lepideptera Order has the characteristics of having two pairs of wings covered in feathers and scales, having a rather long antenna, attractive wing color, larval phase usually in the form of a caterpillar, and having a small or large size. The number of Lepidoptera orders obtained is 8 species, namely Calforis bromus as many as 3 individuals with characteristics that have a wing color that is less attractive compared to butterflies in general, which are brown with white and yellow spots, and relatively short wing sizes. Delias periboea as many as 7 individuals, with special features such as batik which is a combination of black and yellow. Leptosia nina as many as 7 individuals, a special feature is the dominant white wing color with the presence of spots or black dots on both anterior wings. Eurema hecabe merguiana as many as 9 individuals, has a characteristic that is a yellow wing color with black wing edges. Eurema alitha* as many as 7 individuals, has characteristics similar to Eurema hecabe merguiana, but the color of the wings is rather faded yellow. These butterflies have been captured, but because the treatment was done poorly, finally the butterfly was damaged. Appias libythea olferna as many as 6 individuals, with a characteristic that is a wing pattern like batik, with a white base and black hues. 7 Olympic E-Games as many as 7 individuals, have special features in the form of jagged wing edges and a combination of colors on the wings (dark brown color, slightly black and purplish). Junonia atlites* as many as 6 individuals, has a special characteristic that is a style like brown batik with a blend of white and dark brown. This butterfly has been caught but was damaged because when the fixation was wrong, so the wings were torn. As many as 6 Euploea gamelia, have special characteristics, namely wavy wing edges with black wings and regular white spheres.

The Odonata Order has characteristics including moderate to large body size, has a short and stiff antenna, a long and slender abdomen. Type of biting and chewing mouth appliance. Wings like membranes and veins. The Odonata Order lives a lot in aquatic habitats at the time of naphtha and there is land or free air as adults (Noerdji, 2011). The number of Odonata orders obtained is 2 species, namely Orthetrum sabina as many as 2 individuals who have a special characteristic which has 2 pairs of black wings, a green body with segments that intersect between green and black. 7 individual Brachythemis contaminates with medium-sized 
characteristics. Orange from the body to the wings. Segmented tail.

The Hymenoptera order has characteristics such as very small to large body size. The Order of the Hymenoptera has 2 pairs of wings with characteristics such as membranes, with a slight vein, for small ones it has almost no veins, the front wing is larger than the rear wing. There are antennas with a number of 10 segments or more, the type of sucker biting mouth. Female species generally have ovipositors that multiply, some types of ovipositors are modified to become stingers to defend themselves. Habitats of adult species are found in various habitats, most of which are found in flowers or plants, some live on land or in ruins. Order larvae of Hymenoptera exist in plants or in the bodies of other insects (Lilies, 1991). The number of Hymenoptera orders obtained as many as 3 species, namely Rhyncium haemorrhaidale as many as 7 individuals, has a characteristic that is a combination of body color between black and brown. Ropalidia fasciata* as many as 6 individuals, specifically characterized by a dark brown body with a yellow line on the abdomen. This bee has been arrested, but due to improper fixation, the body was broken. Apis cerana as many as $\mathbf{5}$ individuals, has a characteristic that is a bulging black tail with a circular yellow line. Transparent black wings on the margins patterned like spiders' nests. Xylocopa confuse as many as 4 individuals, with special characteristics that are golden yellow and have feathers that are evenly distributed until they reach the legs. We caught this bee, but it was damaged because it was not injected with formalin.

The Diptera Order has characteristics including very small to medium sized bodies. Diptera order has 2 wings (1 pair) which is the front wing, the rear wing reduces it to a dumbbell which serves as a balance tool. Penjiiat mouthwashers and suckers. The larva is called magot, set or singgat, without legs, small head, smooth, thin body. Diptera order habitats in various habitats, like the moist place, in plant tissues or in other insect bodies. Adult species live freely (Lilies, 1991). The number of Diptera orders obtained as many species, namely Musca domestica** as many as 1 individual, with special characteristics, namely the head is black and the stomach is brown, but this fly is not captured, so there are only photos. 1 individual Sarchopaga carnaria, has a special characteristic, namely a greenish body with horizontal lines black and black complexion on the abdomen.

The Order of the Orthoptera has characteristics including medium to large body shape, members of the Orthoptera order have wings and some are wingless. Winged species have two pairs of wings with narrowed long wing shapes, many veins, thickened like parchment paper. The wing behind the membraneus, widens and many veins. Chewer biting mouthpiece. Female species generally have avipositor that multiplies, males have sound producing devices, located in the tibia or abdomen. Order Orthoptera in cultivated plant areas, there is also the environment of the house or residence (Lilies, 1991). The number of orders of Orthoptera obtained is only 1 individual, namely Phlaeoba fomusa which has a special characteristic, namely a tapered head.

Insect diversity around the area of Surabaya Undaan Park is dominated by the order of Leidoptera with 9 species. This is due to the presence of vegetation and habitat around the park to support the survival of the order of the Leidoptera, namely the number of shrubs and flowering plants used for protection and food for the order of the Leidoptera.

\section{CONCLUSION}

Based on the observation, collection, and identification of Insect diversity around the Surabaya Undaan Park, it can be concluded that the diversity of Insects in the area is quite diverse with the discovery of various Insects from various orders, including: Order Lepidoptera, Order Odonata, Order Hymenoptera, order Diptera, and order 
Orthoptera. Comparison of the number of species in each order is different. The number of the most dominant species is the order of Hymenoptera and order Lepidoptera when compared to the number of species in other orders.

\section{REFERENCES}

[1] S. Kahono, "Serangga Taman Nasional Gunung Halimun Jawa Bagian Barat”, Bandung: LIPI, 2010.

[2] Subyanto, "Kunci Determinasi Serangga", Yogyakarta: Kanisius, 1991.

[3] M. Hadi, "Biologi Insekta Entomologi", Yogyakarta: Graha Ilmu, 2009. 